\title{
Use of Encapsulated Stem Cells to Overcome the Bottleneck of Cell Availability for Cell Therapy Approaches
}

\author{
D. Freimark ${ }^{\mathrm{a}}$ \\ P. Pino-Grace ${ }^{a}$ \\ S. Pohla \\ C. Weber ${ }^{a}$ \\ C. Wallrapp ${ }^{b}$ \\ P. Geigle \\ R. Pörtner ${ }^{\mathrm{c}}$ \\ P. Czermak ${ }^{a, d}$ \\ a Institute of Biopharmaceutical Technology, University of Applied Sciences, Gießen \\ ${ }^{\mathrm{b}}$ CellMed AG, Alzenau \\ ${ }^{c}$ Institute of Bioprocess and Biosystems Engineering, University of Technology, Hamburg, Germany \\ ${ }^{\mathrm{d}}$ Department of Chemical Engineering, Kansas State University, Manhattan, KS, USA
}

\section{Key Words \\ Encapsulation · Stem cells · Cell therapy}

\section{Summary}

Nowadays cell-based therapy is rarely in clinical practice because of the limited availability of appropriate cells. To apply cells therapeutically, they must not cause any immune response wherefore mainly autologous cells have been used up to now. The amount of vital cells in patients is limited, and under certain circumstances in highly degenerated tissues no vital cells are left. Moreover, the extraction of these cells is connected with additional surgery; also the expansion in vitro is difficult. Other approaches avoid these problems by using allo- or even xenogenic cells. These cells are more stable concerning their therapeutic behavior and can be produced in stock. To prevent an immune response caused by these cells, cell encapsulation (e.g. with alginate) can be performed. Certain studies showed that encapsulated allo- and xenogenic cells achieve promising results in treatment of several diseases. For such cell therapy approaches, stem cells, particularly mesenchymal stem cells, are an interesting cell source. This review deals on the one hand with the use of encapsulated cells, especially stem cells, in cell therapy and on the other hand with bioreactor systems for the expansion and differentiation of mesenchymal stem cells in reproducible and sufficient amounts for potential clinical use.

\author{
Schlüsselwörter \\ Verkapselung · Stammzellen · Zelltherapie
}

\section{Zusammenfassung}

Heutzutage werden zellbasierte Therapieansätze selten angewendet, da vor allem die Gewinnung geeigneter Zellen problematisch ist. Um Zellen therapeutisch einzusetzen, dürfen diese Zellen im Patienten keine Immunreaktion auslösen, weshalb bislang hauptsächlich körpereigene (autologe) Zellen verwendet werden. Vitale autologe Zellen sind jedoch nur in begrenzter Menge im Patienten vorhanden und bei stark geschädigtem $\mathrm{Ge}$ webe unter Umständen gar nicht mehr. Zudem erfordert ihre Gewinnung zusätzliche Eingriffe am Patienten. Auch ist eine Vermehrung ex vivo sehr (zeit)aufwendig. Andere Ansätze versuchen diese Problematik zu umgehen, indem allo- oder xenogene Zellen eingesetzt werden. Diese Zellen sind meist in ihren therapeutischen Eigenschaften stabiler und können auf Vorrat produziert werden. Damit diese Zellen keine Immunreaktion im Patienten auslösen, werden sie meist mit Alginat verkapselt. Diverse Studien zeigen, dass mit verkapselten allo- und xenogenen Zellen vielversprechende Ergebnisse bei der Behandlung diverser Krankheitsbilder erzielt werden können. Dabei stellen Stammzellen, insbesondere mesenchymale Stammzellen, eine besonders interessante Zellquelle für den therapeutischen Ansatz dar. Diese Übersichtsarbeit behandelt sowohl eine mögliche klinische Anwendung verkapselter Zellen mit dem Schwerpunkt auf dem Einsatz von Stammzellen als auch Systeme zur Expandierung und Differenzierung von mesenchymalen Stammzellen in reproduzierbaren und für einen potentiellen therapeutischen Einsatz ausreichenden Mengen.

\section{KARGER}

Fax +497614520714

Information@Karger.de

www.karger.com (c) 2010 S. Karger GmbH, Freiburg

Accessible online at:

www.karger.com/tmh
Prof. Dr.-Ing. Peter Czermak

Institut für Biopharmazeutische Technologie

Fachhochschule Gießen-Friedberg

Wiesenstraße 14, 35390 Gießen, Germany

Tel. +49 641309 25-51, -Fax -53

peter.czermak@tg.fh-giessen.de 


\section{Introduction}

Cell therapy is described as a process of introducing new cells in human body in order to treat a disease or to restore the function of a tissue. Thereby, cell therapy approaches often focus on degenerative diseases with or without gene therapy. No single cell or universal donor can be used for the treatment of all diseases so that consequently the source and the desired function of the cell will dictate which cell type is most useful for each disease [1]. There are several forms of cell therapy: the transplantation of i) autologous or allogenic stem cells, ii) the transplantation of mature, functional cells, iii) the transplantation of modified human cells that produce a needed substance, iv) the transplantation of transdifferentiated cells and $\mathrm{v}$ ) xenotransplantation.

Although autologous cells have the advantage to cause no immune response and therefore are recommended for cell therapy, the retrieval of appropriate cells in sufficient amounts is difficult. Several diseases are congenital so that potential genetic dispositions causing the disease to be treated are still present in autologous cells. Furthermore, additional surgery is needed. For these reasons, allogenic or even xenogenic cells are attractive cell sources for regenerative medicine. To protect these cells from the immune response and to attain cell survival, encapsulation of such cells is a feasible way.

\section{Encapsulation of Cells for Clinical Application}

Cell encapsulation (fig. 1) means the immobilization of cells within a semi-permeable membrane that allows the diffusion of small molecules (therapeutic proteins, nutrients, oxygen etc.) but protects the cell from the host's immune system and also from mechanical stress [2,3].

There are many biomaterials such as alginate, agarose and other polymers that are used for encapsulation. Existing materials are designed and modified to achieve ideal biocompatibility, degradation and physical properties depending on the field of application [4]. The most common material for cell encapsulation is alginate which forms a three-dimensional structure after reacting with multivalent cations. Similarly to the available biomaterials, the formation methods are multifaceted as well. The most often described method is the formation of a core capsule covered by an outer layer. Due to the fact that this review does not focus on encapsulation technology, the biomaterials and the capsule formation were described shortly. For further reading on these topics several reviews are available [5-8].

Many diseases, particularly chronic diseases, are based on a dysfunction of certain cell types. Cellular processes are very complex, with many regulation and signaling pathways which cannot be imitated in vitro that easily. Therefore, it is very difficult to develop drugs or therapies for the treatment of such diseases based on in vitro studies because the results of these studies are often not able to project a drug effect in vivo. More successful is the implementation of cells which produce a therapeutic protein or restore the tissue function because this corresponds more to the natural behavior and can minimize unintentional side effects. Compared to alternative therapies, the advantages of cell encapsulation are the use of allogenic (non-human) cells as alternative source to the limited supply of donor tissue, the avoidance of permanent immunosupression and, if desired, the delivery of a therapeutic product over long time periods. In addition, genetically modified cells can be induced to produce any protein in vivo without changes in the patient's genome. In comparison to the encapsulation of a therapeutic protein alone, the immobilization of cells allows a continuous and controlled release of a de novo synthesized protein with a constant rate, giving rise to more physiological conditions. Moreover, in case of capsule damage, the fast release of high protein concentrations causing toxicity can be avoided. Due to these reasons, cell therapy with encapsulated cells seems to be a promising approach for many clinical applications.

\section{Primary Cells Used for Cell Therapy Approaches}

Encapsulated primary cells are also known as bioorgans or biohybrids. Most common is the implementation of encapsulated islets of Langerhans mimicking the pancreas for the treatment of diabetes. For this disorder promising results from animal studies were obtained in allo- and xenotransplantation approaches [9-12]. Moreover, initial pilot clinical trials have been made that came to the conclusion that to some extent the function of the pancreas could be restored although the medication with insulin could not completely be discontinued [13-15].

Primary cells are also used in neurodegenerative disease such as Huntington's disease. This disease is caused by a mutation of the protein Hungtingtin which results in the damage of specific areas of the brain. Choroid plexi (CPs) are areas in the brain which produce the cerebrospinal fluid (CSF) and act as a filtration system, removing metabolic waste, foreign substances and excess neurotransmitters from the CSF. In this way the CP helps to maintain an extracellular environment required for optimal brain function [16]. In several studies concerning Huntington's disease, CP was encapsulated and transplanted in the brain of laboratory animals $[17,18]$. In a primate model of Huntington's disease, encapsulated CP delivers neurotrophic growth factors which prevent neurons from degeneration [18]. Furthermore, the secretion of neuroactive substances by encapsulated bovine chromaffin cells gave promising results in the rat model in the treatment of chronic neuropathic pain, another neural disorder [19].

\section{Genetically Engineered Mature Cells Used for Cell Therapy Approaches}

The number of primary cells is limited wherefore other cell sources are needed. One alternative is the genetic engineering of other mature cells to deliver the desired therapeutic pro- 
Fig. 1. A Schematic of encapsulated cells. Metabolites and waste products as well as therapeutic proteins can pass the capsules whereas components of the immune system cannot. B Photography of cells encapsulated with alginate (CellBeads). The cells were encapsulated with a core and an outer layer. This picture was kindly provided by the CellMed AG Alzenau, Germany.
A

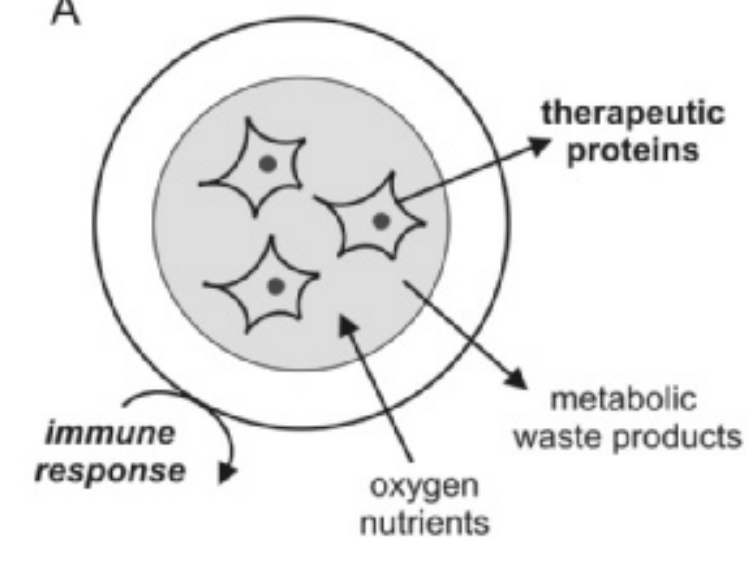

tein. Which cell type will be used depends on the application as well as on processing, storage, availability and costs. For some applications such as cerebral and cardiovascular disorders which are difficult to treat with common medication, encapsulated genetically improved cells could be more suited for therapy as common medicaments.

Genetically engineered fibroblasts (recombinant glial cell line-derived neurotrophic factor (GDNF) production) were encapsulated and investigated concerning their ability in the treatment of Parkinson's disease. In a rat model, GDNF delivery improved the restoration of the nerve function [20, 21]. An encapsulated cell-based system consisting of engineered murine myoblasts was developed to deliver arylsulfatase A to the CNS of metachromatic leukodystrophy patients [22]. To treat myocarditis, microencapsulated xenogenic chinese hamster ovary $(\mathrm{CHO})$ cells expressing vascular endothelial growth factor (VEGF) were implanted into rats. The immune response to the encapsulated $\mathrm{CHO}$ cells was low. The VEGFexpressing $\mathrm{CHO}$ cells significantly increased angiogenesis resulting in improvement of heart function [23]. Other approaches using encapsulated, genetically modified cells are the expression of $\beta$-glucuronidase in epithelial cells treating mucopolysaccharidosis type VII [24], the expression of erythropoietin in myoblast cells $[25,26]$ or the expression of IL-6 in $\mathrm{CHO}$ cells, inhibiting tumor progression [27]. Some cell therapy systems are still in clinical phase trials. For example, the safety of the transplantation of ciliary neurotrophic factor(CNTF)-expressing epithelial cells retarding retina degeneration is tested in a phase I trial [28].

Although the availability of allo- or xenogenic mature cells is not a major problem, cell therapy based on encapsulated mature (allo-/xenogenic) cells still has some limitations. Up to now, the secretion of therapeutic proteins often is only shorttime, and immune response occurs in spite of cell encapsulation.

\section{Stem Cells Used for Cell Therapy Approaches}

Stem cells could reduce the problem of the graft-versus-host disease because, for instance, mesenchymal stem cells (MSCs) are often described as immune privileged [29, 30]. Currently, stem cells still are only rarely used in the encapsulation technology, and most research is based on in vitro studies. Nevertheless, the use of encapsulated stem cells could become one of the main objectives of this technique via implantation of (engineered) stem cells and direction of their specific differentiation.

Stem cells can differentiate into every tissue cell within the organism. Cells characterized as stem cells have the ability of unlimited self-renewal to produce progeny exactly the same as the parental cell. Cancer cells have the property of self-renewal as well, but they divide in an uncontrolled manner, whereas stem cell division is highly regulated. Therefore, a second requirement for stem cells is their ability to differentiate into a specialized cell type that becomes part of the healthy organism [31].

Originally, stem cells were distinguished into embryonic and adult stem cells depending on the developmental stage they originate. New research results have recovered that fully differentiated adult cells can dedifferentiate to embryonic stem cells, and adult stem cells are also found in fetus, placenta and umbilical cord blood [32], suggesting that this classification is insufficient. Therefore, nowadays cells are sorted based on their biological properties in pluripotent and multipotent cells. Pluripotent cells can differentiate into all cell types of the body, multipotent cells only in cell types of a discrete germ line (endoderm, mesoderm and ectoderm) or a particular tissue.

Pluripotent stem cells used in research and development are mainly isolated from the inner cell mass of blastocysts. However, technical hurdles and ethical concerns about the involvement of embryos impede the usage of such cells. An alternative to obtain pluripotent stem cells is the molecular ma- 
nipulation of adult cells, reprogramming them back into 'induced pluripotent stem cells' [33]. Pluripotent stem cells have not yet been used therapeutically in humans because in animal studies formation of large tumors called teratomas was observed [34]. Moreover, no in vivo experiment with encapsulated pluripotent stem cells have been reported. Nevertheless, in animal studies, often with immunodeficient animals, these cells showed a high therapeutic potential and were used for the treatment of diabetes, spinal cord injury and visual impairment by creation of new insulin-producing cells, neurons and retinal cells, respectively [35-37]. Pluripotent stem cells have also been investigated in animal models concerning several diseases such as Parkinson's disease, muscular dystrophy and heart failure [38-40].

Multipotent stem cells are found in almost every tissue in the human body. Cells with the highest differentiation potential are found in the gastrula and are evolutionary restricted to all cells of their germ layer. Unipotent cells have the lowest differentiation potential; they can become only one special cell type. These cells are typically found within their organ and guarantee tissue integrity by serving as cell source to replace aged or injured cells if necessary [31].

The first use of multipotent stem cells for cell therapy was the transplantation of bone marrow to cure several types of blood cancer [41]. This therapy is connected with a strong suppression of the immune system and with the availability of a genetically compatible donor. This means that to some extent multipotent stem cells are still in clinical practice. Nevertheless, the combination of stem cell and encapsulation technology has the potential to expand the current application range of stem cell approaches.

Among several multipotent cell types, MSCs seem to be the ideal candidates for cell-based regeneration because they are of high plasticity and have the capacity of multilineage differentiation [42]. In addition, they are accessible in sufficient quantities from bone marrow [43] and fat tissue [44] and, compared to other cell types, easy to expand and to manipulate [45]. Due to these facts, several experiments with encapsulated MSCs, e.g. investigating their ability to form new bone and cartilage, have been performed [46]. Furthermore, there are efforts for a potential use of encapsulated MSCs for intervertebral disc regeneration [47], heart ailments [48, 49] and kidney regeneration [50].

Often genetically engineered MSCs are used for therapy approaches as well. MSCs expressing the glucagon-like peptide-1 were investigated in clinical trials concerning traumatic brain injury (e.g. stroke). In this case, encapsulated MSCs were implanted cerebrally and significantly improved cellular pathology in the brain [51]. Encapsulated MSCs transfected with the gene of bone morphogenetic protein-2, a potent cytokine for bone formation, were found to induce bone formation [52]. Chondrogenesis could be enhanced in targeted cell population in vitro and in vivo after Sox-9 delivery from encapsulated and genetically improved MSCs [53]. In summary, results with encapsulated MSCs demonstrate their high potential for cell therapy and clinical use. Nevertheless, for an application of cell-based therapies, sufficient amounts of cells have to be expanded under reproducible and highly controlled conditions.

\section{Controlled Expansion, Cultivation and Differentiation of Mesenchymal Stem Cells}

It has to be mentioned that, unlike to traditional cell culture processes in which a secreted protein or a virus should be produced, the purpose of stem cell cultivation is to expand stem cells and sustain their multipotency, meaning that the cell itself is the desired product. Therefore, other culture requirements are necessary which include an efficient cell harvesting strategy. Moreover, the quality of the cells, in that case the retention of self-renewal and differentiation ability, is critical and has to be examined, for instance by detection of surface markers, morphology or other characteristics.

In general, the selection of a bioreactor system for cell cultivation beyond bench scale is largely dependent on whether cells grow adherent or in suspension. As many other stem cell types, MSCs are strictly anchorage-dependent and therefore need a surface to attach and proliferate. Simple ways for the cultivation of adherent cells in larger quantities are monolayer culture flasks such as roller bottles or multiple plate vessels. Further, cells can be grown on carrier in stirred vessels (e.g. spinner flasks, fermentors) or bed reactors which are easy to operate and can be equipped with online monitoring instruments for environmental control. Beside the difficulties with scale-up and process control, monolayer cultures show several disadvantages especially for the cultivation of MSCs. It has been shown that in static monolayer cultures MSCs proliferate slower, and the differentiation potential is affected as well [54]. Therefore, the use of bioreactors is an alternative to the static expansion in flasks. Bioreactors provide conditions similar to the in vivo situation of the cells, including advantages such as efficient nutrient supply, waste removal, minimal shear stress and the possibility to control the cultivation via online measurements of critical values [55]. With respect to bioreactor cultivation, an MSC expansion on 3D scaffolds in a perfusion system [56] and an expansion in a rotary cell culture system [57] have been published. Both studies showed an increase in MSC growth and higher cell densities compared to static cultures without affecting the stem cell fate and the differentiation ability.

In our work group, alternative concepts for human MSC (hMSC) expansion were investigated aiming at a high product quality and a reproducible and controlled cultivation. One approach comprised the expansion of hMSCs on non-porous microcarriers in spinner flasks. Although non-porous carriers have a reduced growth surface compared to porous carriers, the separation of the cells after the enzymatic detachment is 
Fig. 2. Fixed-bed reactor system for stem cell expansion. The bioreactor consists of a glass cylinder filled with glass spheres as bed. Oxygen measurements are performed on-line with optical sensors (IPO2) at the in- and the outlet of the reactor. The cells are transferred into the reactor from an inoculum vessel. The following cultivation runs automatically with a perfusion of the reactor with preconditioned medium. Medium exchange is done if necessary whereby the exchanged medium is collected in the waste vessel. For the cell harvest, the reactor is automatically washed with PBS, followed by incubation with enzyme solution for cell detachment. The detachment is stopped by addition of medium and detached cells are collected in the collecting vessel.

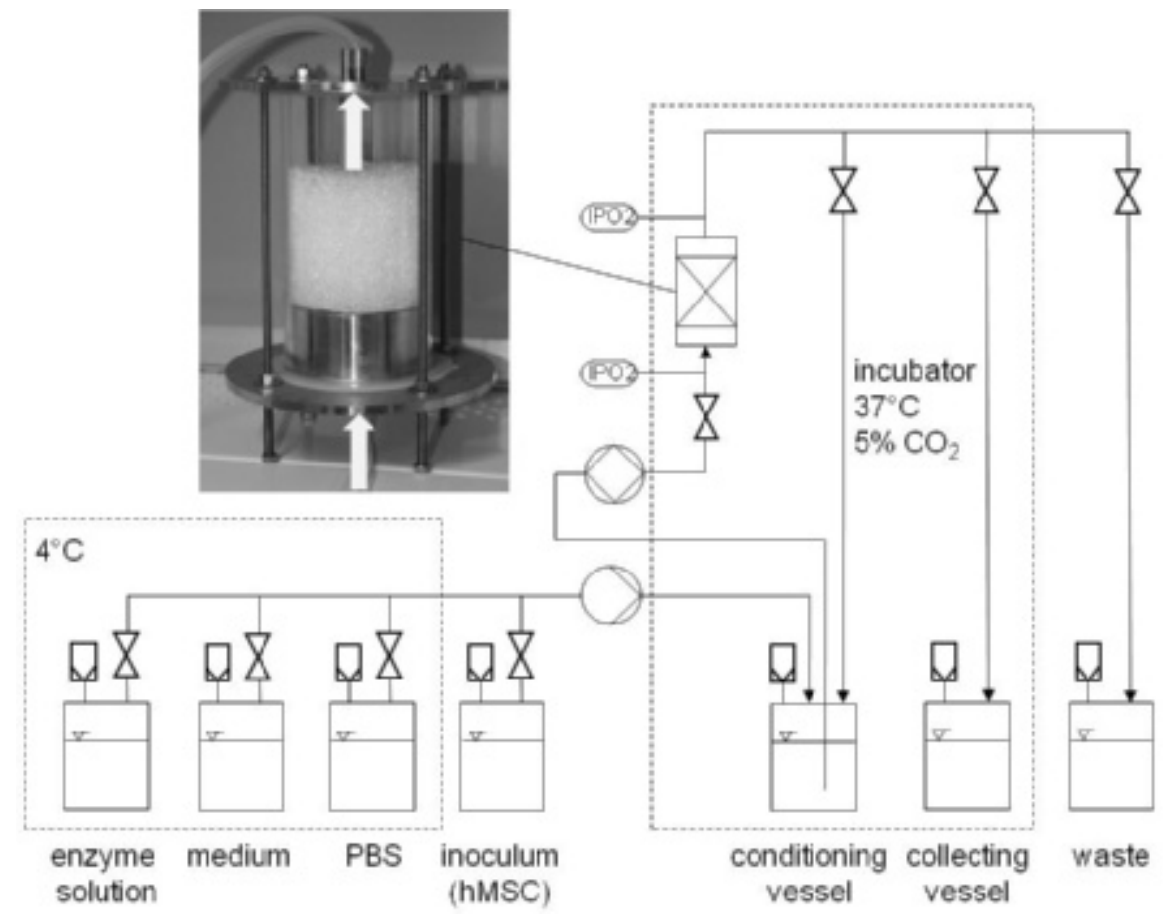

simpler and leads to higher yields. Several carrier types were examined with respect to cell growth and cell harvest, including the investigation of different seeding densities and different enzymes for cell detachment. Our results showed that a decreased seeding density and the use of a borosilicate carrier (e.g. Biosilon or RapidCell) were superior concerning cell growth and harvest. Further, the differentiation potential of the hMSCs was influenced neither by cultivation nor by harvest procedure [58]. Another approach was the expansion of the hMSCs on non-porous glass spheres in a fixed-bed reactor. Compared to suspension reactors, this system has the advantage of a high volume-specific cell density and productivity, low shear stress, an easy medium exchange and a high process control [55]. In figure 2, a scheme of the reactor consisting of a glass cylinder and the corresponding periphery is shown. The oxygen consumption of the cells was monitored online by measuring the oxygen concentration at the in- and outlet of the reactor, whereas the metabolites were measured offline. Our results demonstrated that using this reactor system hMSCs can be expanded and harvested with a high cell density and vitality. The harvested stem cells were neither differentiated nor affected in their differentiation potential. The reactor system was designed very simple allowing its use as disposable system. Moreover, it is automatable and offers an online process control of several parameters. In summary, this system is suitable for operation under GMP conditions [59, 60].

While expansion and differentiation of hMSCs are often done in the same reactor and during the same cultivation, our workgroup decided to separate the cell expansion and the cell differentiation cultivation. After expansion, the hMSCs were harvested and encapsulated with alginate. The cell encapsulation was done by one of our cooperation partners (CellMed AG, Alzenau, Germany). The generated capsules (CellBeads $\left.^{\circledR}\right)$ are implantable therapeutic cell systems with potential for disease treatment in vivo. The CellBeads itself form the bed of a fixed-bed system which is used to differentiate the hMSCs inside the capsule. Moreover, the bioreactor consists of a disposable syringe which can be used as implantation tool for the CellBeads after finishing the differentiation. An overview of the differentiation system is shown in figure 3 . Our results demonstrated that it is possible to differentiate hMSCs without significant loss of cell vitality using this reactor system. Moreover, the whole system can satisfy GMP requirements [61]. The presented studies indicate that it is possible to expand and differentiate hMSCs in good quality in bioreactor systems. Nonetheless, some problems are still to solve, particularly with regard to the requirements of the Process Analytical Technology (PAT) initiative of the Food and Drug Administration (FDA). In this case, the term PAT is defined as follows: 'The agency considers PAT to be a system for designing, analyzing, and controlling manufacturing through timely measurements (i.e., during processing) of critical quality and performance attributes of raw and in-process materials and processes, with the goal of ensuring final product quality. It is important to note that the term analytical in PAT is viewed broadly to include chemical, physical, microbiological, mathematical, and risk analysis conducted in an integrated manner' [62]. 
Fig. 3. Fixed-bed reactor system for the differentiation of encapsulated stem cells. The bioreactor consists of a sterile plastic syringe filled with cell capsules as bed. The cell capsules are transferred into the reactor from an inoculum vessel. The following cultivation runs automatically with a perfusion of the reactor with preconditioned medium. Oxygen measurements are performed on-line with optical sensors (IPO2) at the in- and the outlet of the reactor. Medium exchange is done if necessary whereby the exchanged medium is collected in the waste vessel. After completion of the differentiation, the cell capsules are cryopreserved. Therefore, they are automatically washed with PBS, followed by addition of a cryoprotective medium.

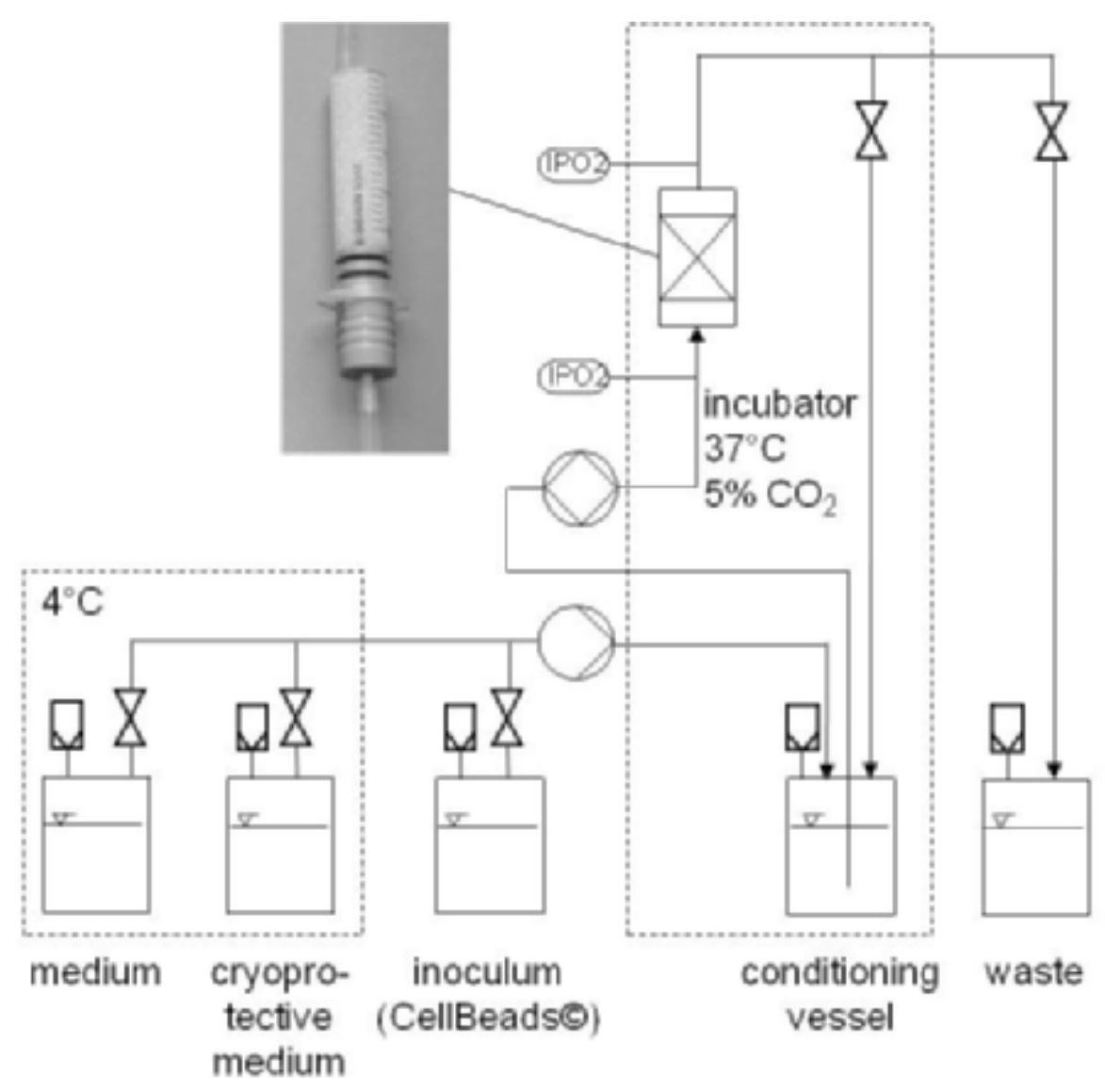

\section{Conclusion and Outlook}

In summary, encapsulation technology, especially in combination with stem cells, achieves many interesting results with good aspects for a putative clinical application. To realize clinical practice, some challenges in the field of material science and encapsulation technology and also in the field of cell biology are to overcome.

On the material side, effort has been made in the availability of clinical-grade polymers. Alginate is often the material of the choice, but only few years ago there was a lack of a standardized polymer with low protein and endotoxin content. Now some companies (e.g. CellMed AG) have specialized on the purification of alginate guaranteeing clinical-grade qualities. Another challenge is the formation of uniform capsules with excellent repeatability and reproducibility. In general, it seems to be a problem that cells agglutinate during encapsulation so that empty beads are produced. One prospect is to distinguish between empty and filled capsules. Moreover, many approaches need a defined stability of the cell capsules which has to be controlled by the material properties. Up to now, it is not possible to create materials with such degradation behaviors.

On the biological side there is a need of suitable cells for immobilization. As outlined in the text, allogenic or even xenogenic cells are alternatives to patient's own cells. Because of ethical reasons and a lower risk of virus transfer, allogenic cells were preferred. Mature, differentiated cells cannot be expanded that easy thus stem cells, particularly MSCs, are an interesting cell source. Characteristics of isolated hMSCs are varying very strongly depending on the source and the method of isolation. This may be problematic in clinical approaches because up to now no marker for hMSC exists. Moreover, some isolated MSCs have lost their adipogenic or chondrogenic differentiation potential. As many primary cells, the characteristics of MSCs changed with increasing population doublings as well. To achieve a constant and reproducible cell quality, a 'standardized' hMSC is needed. A option may be the use of hMSC-TERT cells which are genetically improved MSCs. In the genome of these cells the gene of the catalytic subunit of human telomerase is integrated that prevents telomere shortening. These cells can sustain much more population doublings than primary MSCs without any significant changes [63].

Beside the quality of the cells itself, the transplantation site of the cell capsules plays a critical role for the effort of the therapy. Among other things, these include the nutrition of the encapsulated cells and the need of vascularization. To satisfactorily answer these questions, the number of suitable in vivo investigations is still not sufficient. Moreover, the re- 
searchers have to clarify the point if cell encapsulation really protects the cells from host's immune response. Most in vivo experiments have been done in immune-suppressed animals or patients. Furthermore, some cell types such as MSCs are thought to be immune privileged so that it is questionable if encapsulation is needed for that purposes.

\section{Acknowledgement}

We would like to thank the Hesse State Ministry of Higher Education, Research and the Arts for the financial support within the Hesse initiative for scientific and economic excellence (LOEWE Program). Moreover, the authors would like to thank the Federal Ministry of Economics and Technology of Germany for financial support (KF0143002UL5) as well as the CellMed AG for providing the hMSCs and the CellBeads.

\section{Disclosure}

The authors declared no conflict of interest.

\section{References}

1 Gage FH: Cell therapy. Nature 1998;392(6679 suppl):18-24.

2 Morris PJ: Immunoprotection of therapeutic cell transplants by encapsulation. Trends Biotechnol 1996;14(5):163-167.

3 Rihova B: Immunocompatibility and biocompatibility of cell delivery systems. Adv Drug Deliv Rev 2000;42(1-2):65-80.

- 4 Li RH: Materials for immunoisolated cell transplantation. Adv Drug Deliv Rev 1998;33(1-2) 87-109.

- 5 Uludag H, De Vos P, Tresco PA: Technology of mammalian cell encapsulation. Advanced Drug Delivery Rev 2000;42(1-2):29-64.

6 Shoichet MS, Li RH, White ML, Winn SR: Stability of hydrogels used in cell encapsulation: An in vitro comparison of alginate and agarose. Biotechnol Bioeng 1996;50(4):374-381.

7 Zimmermann H, Shirley SG, Zimmermann U: Alginate-based encapsulation of cells: past, present, and future. Curr Diab Rep 2007;7(4):314-320.

-8 Rabanel JM, Banquy X, Zouaoui H, Mokhtar M, Hildgen P: Progress technology in microencapsulation methods for cell therapy. Biotechnol Prog 2009;25(4):946-963.

$\checkmark$ Gianello P, Dufrane D: Correction of a diabetes mellitus type 1 on primate with encapsulated islet of pig pancreatic transplant (in French). Bull Mem Acad R Med Belg 2007;162(10-12):439-449; discussion 449-450.

10 Thanos CG, Elliott RB: Encapsulated porcine islet transplantation: an evolving therapy for the treatment of type I diabetes. Expert Opin Biol Ther 2009;9(1):29-44.

11 Black SP, Constantinidis I, Cui H, Tucker-Burden C, Weber CJ, Safley SA: Immune responses to an encapsulated allogeneic islet beta-cell line in diabetic NOD mice. Biochem Biophys Res Commun 2006;340(1):236-243.

12 Altman JJ, Houlbert D, Chollier A, Leduc A, McMillan P, Galletti PM: Encapsulated human islet transplants in diabetic rats. Trans Am Soc Artif Intern Organs 1984;30:382-386.

-13 Elliott RB, Escobar L, Tan PL, Muzina M, Zwain S, Buchanan C: Live encapsulated porcine islets from a type 1 diabetic patient $9.5 \mathrm{yr}$ after xenotransplantation. Xenotransplantation 2007;14(2):157-161

14 Scheen AJ: Clinical study of the month. Prolonged insulin independence after transplantation of islets of Langerhans in a patient with type 1 diabetes: achievement of a dream? (in French). Rev Med Liege 2000;55(8):803-805.
15 Calafiore R, Basta G, Luca G, Lemmi A, Montanucci MP, Calabrese G, Racanicchi L, Mancuso F, Brunetti P: Microencapsulated pancreatic islet allografts into nonimmunosuppressed patients with type 1 diabetes: first two cases. Diabetes Care 2006; 29(1):137-138.

16 Emerich DF, Vasconcellos AV, Elliott RB, Skinner SJ, Borlongan CV: The choroid plexus: function, pathology and therapeutic potential of its transplantation. Expert Opin Biol Ther 2004; 4(8):1191-1201.

17 Borlongan CV, Thanos CG, Skinner SJ, Geaney M, Emerich DF: Transplants of encapsulated rat choroid plexus cells exert neuroprotection in a rodent model of Huntington's disease. Cell Transplant 2008;16(10):987-992.

18 Emerich DF, Thanos CG, Goddard M, Skinner SJ, Geany MS, Bell WJ, Bintz B, Schneider P, Chu Y, Babu RS, Borlongan CV, Boekelheide K, Hall S, Bryant B, Kordower JH: Extensive neuroprotection by choroid plexus transplants in excitotoxin lesioned monkeys. Neurobiol Dis 2006;23(2): 471-480.

19 Jeon Y, Kwak K, Kim S, Kim Y, Lim J, Baek W: Intrathecal implants of microencapsulated xenogenic chromaffin cells provide a long-term source of analgesic substances. Transplant Proc 2006; 38(9):3061-3065.

20 Yasuhara T, Date I: Intracerebral transplantation of genetically engineered cells for Parkinson's disease: toward clinical application. Cell Transplant 2007;16(2):125-132.

21 Sajadi A, Bensadoun JC, Schneider BL, Lo Bianco C, Aebischer P: Transient striatal delivery of GDNF via encapsulated cells leads to sustained behavioral improvement in a bilateral model of Parkinson disease. Neurobiol Dis 2006;22(1):119-129.

22 Consiglio A, Martino S, Dolcetta D, Cusella G, Conese M, Marchesini S, Benaglia G, Wrabetz L, Orlacchio A, Deglon N, Aebischer P, Severini GM, Bordignon C: Metabolic correction in oligodendrocytes derived from metachromatic leukodystrophy mouse model by using encapsulated recombinant myoblasts. J Neurol Sci 2007;255(1-2):7-16.

23 Zhang H, Zhu SJ, Wang W, Wei YJ, Hu SS: Transplantation of microencapsulated genetically modified xenogeneic cells augments angiogenesis and improves heart function. Gene Ther 2008;15(1):40-48.

24 Nakama H, Ohsugi K, Otsuki T, Date I, Kosuga M, Okuyama T, Sakuragawa N: Encapsulation cell therapy for mucopolysaccharidosis type VII using genetically engineered immortalized human amniotic epithelial cells. Tohoku J Exp Med 2006; 209(1):23-32.
25 Murua A, de Castro M, Orive G, Hernandez RM, Pedraz JL: In vitro characterization and in vivo functionality of erythropoietin-secreting cells immobilized in alginate-poly-L-lysine-alginate microcapsules. Biomacromolecules 2007;8(11):3302-3307.

26 Murua A, Orive G, Hernandez RM, Pedraz JL: Xenogeneic transplantation of erythropoietin-secreting cells immobilized in microcapsules using transient immunosuppression. J Control Release 2009; 137(3):174-178.

27 Moran DM, Koniaris LG, Jablonski EM, Cahill PA, Halberstadt CR, McKillop IH: Microencapsulation of engineered cells to deliver sustained high circulating levels of interleukin-6 to study hepatocellular carcinoma progression. Cell Transplant 2006;15(8-9):785-798

28 Sieving PA, Caruso RC, Tao W, Coleman HR, Thompson DJ, Fullmer KR, Bush RA: Ciliary neurotrophic factor (CNTF) for human retinal degeneration: phase I trial of CNTF delivered by encapsulated cell intraocular implants. Proc Natl Acad Sci U S A 2006;103(10):3896-3901.

29 Puymirat E, Geha R, Tomescot A, Bellamy V, Larghero J, Trinquart L, Bruneval P, Desnos M, Hagege A, Puceat M, Menasche P: Can mesenchymal stem cells induce tolerance to cotransplanted human embryonic stem cells? Mol Ther 2008;17(1):176-182.

30 Niemeyer P, Seckinger A, Simank HG, Kasten P, Sudkamp N,Krause U: Allogenic transplantation of human mesenchymal stem cells for tissue engineering purposes: an in vitro study (in German). Orthopäde 2004:33(12):1346-1353.

31 Biehl JK, Russell B: Introduction to stem cell therapy. J Cardiovasc Nurs 2009;24(2):98-103.

32 Bajada S, Mazakova I, Richardson JB, Ashammakhi N: Updates on stem cells and their applications in regenerative medicine. J Tissue Eng Regen Med 2008;2(4):169-183.

33 Feng B, Ng JH, Heng JC, Ng HH: Molecules that promote or enhance reprogramming of somatic cells to induced pluripotent stem cells. Cell Stem Cell 2009;4(4):301-312

34 Blum B, Benvenisty N: The tumorigenicity of human embryonic stem cells. Adv Cancer Res 2008; 100:133-158.

35 Evans-Molina C, Vestermark GL, Mirmira RG: Development of insulin-producing cells from primitive biologic precursors. Curr Opin Organ Transplant 2009;14(1):56-63. 
36 McDonald JW, Becker D, Holekamp TF, Howard M, Liu S, Lu A, Lu J, Platik MM, Qu Y, Stewart T, Vadivelu S: Repair of the injured spinal cord and the potential of embryonic stem cell transplantation. J Neurotrauma 2004;21(4):383-393.

37 Haruta M: Embryonic stem cells: potential source for ocular repair. Semin Ophthalmol 2005; 20(1):17-23.

\38 Taylor H, Minger SL: Regenerative medicine in Parkinson's disease: generation of mesencephalic dopaminergic cells from embryonic stem cells. Curr Opin Biotechnol 2005;16(5):487-492.

39 Price FD, Kuroda K, Rudnicki MA: Stem cel based therapies to treat muscular dystrophy. Biochim Biophys Acta 2007;1772(2):272-283.

40 Pillekamp F, Khalil M, Emmel M, Brockmeier K, Hescheler J: Stem cells in pediatric heart failure. Minerva Cardioangiol 2008;56(3):335-348.

41 Thomas ED: Bone marrow transplantation: prospects for leukemia and other conditions. Proc Inst Med Chic 1975;30(8):256-258.

42 Pittenger MF, Mackay AM, Beck SC, Jaiswal RK, Douglas R, Mosca JD, Moorman MA, Simonett DW, Craig S, Marshak DR: Multilineage potential of adult human mesenchymal stem cells. Science 1999;284(5411):143-147.

43 Tuli R, Seghatoleslami MR, Tuli S, Wang ML, Hozack WJ, Manner PA, Danielson KG, Tuan RS A simple, high-yield method for obtaining multipotential mesenchymal progenitor cells from trabecular bone. Mol Biotechnol 2003;23(1):37-49.

44 Fraser JK, Wulur I, Alfonso Z, Hedrick MH: Fat tissue: an underappreciated source of stem cells for biotechnology. Trends Biotechnol 2006;24(4): 150-154.

45 Weber C, Gokorsch S, Czermak P: Expansion and chondrogenic differentiation of human mesenchymal stem cells. Int J Artif Organs 2007;30(7): 611-618.
46 Cai X, Lin Y, Ou G, Luo E, Man Y, Yuan Q, Gong P: Ectopic osteogenesis and chondrogenesis of bone marrow stromal stem cells in alginate system. Cell Biol Int 2007;31(8):776-783.

47 Freimark D, Czermak P: Cell-based regeneration of intervertebral disc defects: review and concepts. Int J Artif Organs 2009;32(4):197-203.

48 Ohnishi S, Nagaya N: Prepare cells to repair the heart: mesenchymal stem cells for the treatment of heart failure. Am J Nephrol 2007;27(3):301-307.

49 Mathur A, Martin JF: Stem cells and repair of the heart. Lancet 2004;364(9429):183-192.

50 Poulsom R, Alison MR, Cook T, Jeffery R, Ryan E, Forbes SJ, Hunt T, Wyles S, Wright NA: Bone marrow stem cells contribute to healing of the kidney. J Am Soc Nephrol 2003;14(suppl 1):S48-54

51 Heile AM, Wallrapp C, Klinge PM, Samii A, Kassem M, Silverberg G, Brinker T: Cerebral transplantation of encapsulated mesenchymal stem cells improves cellular pathology after experimental traumatic brain injury. Neurosci Lett 2009; 463(3):176-181.

52 Ding HF, Liu R, Li BG, Lou JR, Dai KR, Tang TT: Biologic effect and immunoisolating behavior of BMP-2 gene-transfected bone marrow-derived mesenchymal stem cells in APA microcapsules. Biochem Biophys Res Commun 2007;362(4):923-927.

53 Babister JC, Tare RS, Green DW, Inglis S, Mann S, Oreffo RO: Genetic manipulation of human mesenchymal progenitors to promote chondrogenesis using 'bead-in-bead' polysaccharide capsules. Biomaterials 2008;29(1):58-65.

54 Braccini A, Wendt D, Jaquiery C, Jakob M, Heberer M, Kenins L, Wodnar-Filipowicz A, Quarto R, Martin I: Three-dimensional perfusion culture of human bone marrow cells and generation of osteoinductive grafts. Stem Cells 2005;23(8):1066-1072.
55 Catapano G, Czermak P, Eibl R, Eibl D, Pörtner $\mathrm{R}$ : Bioreactor design and scale-up; in Eibl R, et al (eds): Cell and Tissue Reaction Engineering. Berlin, Springer 2008, pp 363.

56 Zhao F, Ma T: Perfusion bioreactor system for human mesenchymal stem cell tissue engineering: dynamic cell seeding and construct development. Biotechnol Bioeng 2005;91(4):482-493

57 Chen X, Xu H, Wan C, McCaigue M, Li G: Bioreactor expansion of human adult bone marrowderived mesenchymal stem cells. Stem Cells 2006; 24(9):2052-2059.

58 Weber C, Pohl S, Portner R, Wallrapp C, Kassem M, Geigle P, Czermak P: Expansion and harvesting of hMSC-TERT. Open Biomed Eng J 2007;1:38-46.

59 Weber C, Pohl S, Poertner R, Pino-Grace P, Wallrapp $\mathrm{C}$, Geigle $\mathrm{P}$, Czermak P: Bioreactor system for expansion and differentiation of human mesenchymal stem cells: design and scale-up strategy. GIT Bioprocessing 2009;1:9-13.

60 Weber C, Pohl S, Poertner R, Pino-Grace P, Wallrapp C, Geigle P, Czermak P: Production process for stem cell based therapeutic implants: expansion of the production cell line and cultivation of encapsulated cells. Adv Biochem Eng Biotechnol 2010; DOI: 10.1007/10_2009_25.

61 Weber C, Pohl S, Portner R, Wallrapp C, Kassem M, Geigle P, Czermak P: Cultivation and differentiation of encapsulated hMSC-TERT in a disposable small-scale syringe-like fixed bed reactor. Open Biomed Eng J 2007;1:64-70.

62 Hinz DC: Process analytical technologies in the pharmaceutical industry: the FDA's PAT initiative. Anal Bioanal Chem 2006;384(5):1036-1042.

63 Simonsen JL, Rosada C, Serakinci N, Justesen J, Stenderup K, Rattan SIS, Jensen TG, Kassem M Telomerase expression extends the proliferative life-span and maintains the osteogenic potential of human bone marrow stromal cells. Nat Biotech 2002;20(6):592-596. 